\title{
Obesity and Prognostic Variables in Colombian Breast Cancer Patients: A Cross-Sectional Study
}

\author{
Javier Cuello-López, ${ }^{1}$ Ana Fidalgo-Zapata, ${ }^{2}$ and Elsa Vásquez-Trespalacios ${ }^{3}$ \\ ${ }^{1}$ Clinical Oncology Group, Fundación Colombiana de Cancerología-Clínica Vida, Medellín, Colombia \\ ${ }^{2}$ Breast Surgeon Fellowship Program, School of Medicine, CES University, Medellín, Colombia \\ ${ }^{3}$ Department of Clinical Epidemiology, School of Medicine, CES University, Medellín, Colombia \\ Correspondence should be addressed to Javier Cuello-López; jamacl@hotmail.com
}

Received 24 January 2017; Accepted 12 April 2017; Published 18 May 2017

Academic Editor: Owen A. Ung

Copyright (C) 2017 Javier Cuello-López et al. This is an open access article distributed under the Creative Commons Attribution License, which permits unrestricted use, distribution, and reproduction in any medium, provided the original work is properly cited.

\begin{abstract}
Introduction. Obesity is an established risk factor for cancer and cancer-related deaths, including that of the breast. While the prevalence of female obesity has accelerated over the past decade in many developing countries, such as Colombia, the prevalence of overweight and obesity specifically in breast cancer populations has not been fully described. Methods. A cross-sectional study including 849 women diagnosed with breast cancer between 2009 and 2014. Based on body mass index, prevalence of overweight $(\mathrm{BMI} \geq 25<30)$ and obesity $(\mathrm{BMI} \geq 30)$ and associations of BMI with clinical and tumor histopathological features were analyzed. Results. Colombian breast cancer patients had a prevalence of overweight of $34.28 \%$ and obesity of $28.15 \%$. Mean BMI was comparable between premenopausal and postmenopausal women (27.2 versus 27.7, resp.). Among premenopausal women, higher BMI was significantly positively associated with hormone receptor negative tumors, as well as with greater lymphovascular invasion. Conclusions. Colombian breast cancer patients exhibit a significant prevalence of overweight and obesity. Associations of high BMI and poor prognosis variables in the premenopausal population suggest risk of aggressive disease in this population. Future studies to further validate our observations are warranted in order to implement multidisciplinary clinical guidelines.
\end{abstract}

\section{Introduction}

Overweight and obesity are current escalating public health issues. Close to one billion people worldwide are considered overweight (range of 25 to $29.0 \mathrm{~kg} / \mathrm{m}^{2}$ ), and as many as 475 million are obese $\left(B M I \geq 30 \mathrm{~kg} / \mathrm{m}^{2}\right)$ [1]. Moreover, it is estimated that, by the year 2030, half of the world's population will be obese [2]. Moreover, in developing countries, obesity is an established risk factor for several cancer and cancerrelated deaths [3].

Breast cancer is the leading cause of cancer and the second cause of cancer-related death worldwide [4]. It is estimated that globally, every year 1.671.149 new cases are diagnosed, and 521,907 patients succumb to this disease [5]. While incidence of breast cancer has steadily increased over the past decades, mortality rates are decreasing likely due to early detection and more effective therapies $[6,7]$. Incidence rates vary nearly fourfold across the world regions, in less developed regions (324,000 deaths). In Colombia the annual incidence is 33,5 per 100,000 persons according to data Globocan 2012, with an annual mortality of 9,8 and estimated prevalence of 18.582 cases per 100,000 persons [5].

Furthermore, the identification of risk factors and comorbidities affecting breast cancer incidence or progression has become a matter of intense research [8].

The mechanisms by which obesity affects breast cancer incidence and progression are not fully understood; however, previous studies have proposed both direct and indirect mechanisms. Among the direct mechanisms are insulin resistance, inflammation, and altered adipokine profile (increased levels of leptin and decreased levels of adiponectin). These mechanisms can stimulate breast cells to increase estrogen production, which in turn will stimulate proliferation and signaling through the estrogen receptor (ER). Among 
the indirect mechanisms are included disease detection at advanced stage and subtherapeutic or increased treatment doses [1, 9-12].

Additionally, descriptive studies, systematic reviews, and meta-analysis have shown that obese breast cancer patients have worse survival in both pre- and postmenopausal women. This was observed regardless of whether the BMI was assessed before, during, or after treatment. Furthermore, at the time of diagnosis, obese patients have greater tumor size, grade, and more advanced stage $[1,9,11,13-16]$.

In Colombia, in 2005, $49.6 \%$ of women and $39.9 \%$ of men between the ages of 18 and 64 years were either overweight or obese [17]. More recent data suggest that this population is expanding, as in 2010 over half (51.2\%) of the population of that same age group was overweight to some extent, being $34.6 \%$ overweight (BMI $\geq 25 \leq 30$ ) and $16.5 \%$ obese (BMI $\geq 30$ ). In those studies, excess of weight was more prevalent in women than in men $(55,2 \%$ versus $45,6 \%)$, especially as obesity (20,1\% versus $11,5 \%)$. At the national level, morbid obesity (BMI $\geq 40$ ) was $0.9 \%$ of the adult population, also being more prevalent in women than in men [17-19]. Collectively, these studies show that excess of weight, both as obesity and morbid obesity, is more prevalent in Colombian women than in men.

To date, in Colombia there are no local or national studies reporting the prevalence of obesity specifically in breast cancer patients. In this work we describe the prevalence of obesity in breast cancer patients and analyze the relationship of BMI and prognostic factors in this population.

\section{Materials and Methods}

2.1. Study Design and Participants. This was a cross-sectional study of 849 women diagnosed with breast cancer between January 2009 and December 2014. Participants were recruited of the Fundación Colombiana de Cancerología-Clínica Vida, in Medellín, Colombia. The Ethics Committee at our institution approved this study. Patient data was collected from available electronic databases.

2.2. Variables. Participant's body weight, height, and body mass index $\left[\mathrm{BMI}=\right.$ weight $(\mathrm{kg}) /$ height $\left.^{2}\left(\mathrm{~cm}^{2}\right)\right]$ were collected at the time of diagnosis. Patients were classified following the Center for Disease control's (CDC) criteria: underweight $\left(\mathrm{BMI}<18.5 \mathrm{~kg} / \mathrm{m}^{2}\right)$, normal $\left(18.5 \leq \mathrm{BMI}<25 \mathrm{~kg} / \mathrm{m}^{2}\right)$, overweight $\left(25 \leq \mathrm{BMI}<30 \mathrm{~kg} / \mathrm{m}^{2}\right)$, and obese $\left(\mathrm{BMI} \geq 30 \mathrm{~kg} / \mathrm{m}^{2}\right)$ [20].

Menopausal status was defined by one of the following criteria: age $\geq 60$ years old; history of bilateral oophorectomy; amenorrhea for more than 1 year (in the absence of chemotherapy, tamoxifen, or ovarian suppression); postmenopause levels of FSH, LH, or estradiol. Patients with bilateral breast cancer or inadequate disease staging were excluded from the study.

The following prognostic clinical factors were analyzed: stage (TNM by AJCC 2010), histologic grade, and lymphovascular invasion. Expressions of hormone receptors (estrogen and progesterone receptors), Ki67, and Her2 receptor were detected by immunohistochemistry (IHC). FISH studies were performed in samples in which Her2 immunohistochemistry was inconclusive or borderline.

Based on IHC results, tumors were classified as the following subtypes: luminal A (ER + and/or PR+, Ki67 < 14\%, and Her2-negative), luminal $\mathrm{B}$ negative (ER + and/or $\mathrm{PR}+$, $\mathrm{Ki} 67 \geq 14 \%$, and Her2-negative), luminal B positive (ER + and/or PR+, Ki67 $\geq 14 \%$, and Her2-positive), HER2-enriched (ER-negative, PR-negative, and HER2-positive), and triple negative (ER/PR and Her2 negative) [21].

2.3. Data and Statistical Analysis. Data were analyzed using SPSS $^{\circledR}$ (Windows version) software. For all tests, a $p$ value $<0.05$ was considered statistically significant. Associations between body weight and other variables were examined using Chi-square and Fisher tests.

Quantitative variables are shown as averages and their respective measures of statistical dispersion. Qualitative variables were represented as percentages. Statistical significance of averages was examined by Student's $t$-test (for independent samples) or Mann-Whitney $U$ test as needed.

\section{Results}

3.1. Patient Characteristics. A total of 849 participants diagnosed with breast cancer were recruited for this retrospective study. Mean age was 54 years, ranging from 26 to 91 years old. Of these, $496(58.42 \%)$ were premenopausal and the remaining $353(41.58 \%)$ were postmenopausal. Based on BMI, patients were classified into four groups: underweight, normal, overweight, and obese. In our sample, there was a prevalence of overweight of $34.28 \%$ and of obesity of $28.15 \%$ (Table 1).

3.2. BMI and Menopausal Status. Mean BMI was comparable between pre- and postmenopausal women, being $27.2 \%$ in both groups $(p=0.443)$ (Table 2$)$. While premenopausal women showed a slightly lower prevalence of obesity than postmenopausal participants (26.7\% versus $31.1 \%)$, this trend was not statistically significant $(p=0.482)$ (Table 2$)$.

\subsection{Correlations of BMI and Breast Cancer Histopatho-} logic Features. Correlations between BMI and each of the tumor pathology variables were analyzed in pre- and postmenopausal groups. With regard to hormone receptor status, we found increased BMI to be associated with having ERnegative $(p=0.046)$ as well as PR-negative tumors $(p=$ 0.042 ) in the premenopausal group. Furthermore, compared to normal-weight patients, BMI > 25 patients had a higher frequency of PR-negative tumors (30.3\% versus $44.3 \%, p=$ 0.042 ) (Figure 1(a)). This correlation was not observed in the postmenopausal group (Figure 1(b)). Among obese patients, a correlation between high BMI and hormone receptor positive tumors was found in the postmenopausal group and not in the premenopausal group (Figure 1).

Regarding molecular subtypes, luminal A breast tumors were found to be associated with greater BMIs $(p=0.003)$ in the postmenopausal group. This correlation was not observed 
TABLE 1: Patient demographic and tumor histopathologic characteristics.

\begin{tabular}{|c|c|}
\hline Characteristics & $N=849$ \\
\hline Mean age at time of diagnosis in years (range) & $54(26-91)$ \\
\hline \multicolumn{2}{|l|}{ Age groups, years, $n(\%)$} \\
\hline$<35$ years & $41(4.83)$ \\
\hline $35-39$ & $41(4.83)$ \\
\hline $40-49$ & $245(28.86)$ \\
\hline $50-59$ & $223(26.27)$ \\
\hline $60-69$ & $172(20.26)$ \\
\hline$\geq 70$ & $127(14.96)$ \\
\hline Menopausal status, $n(\%)$ & $n(\%)$ \\
\hline Premenopausal & $496(58.42)$ \\
\hline Postmenopausal & $353(41.58)$ \\
\hline BMI, mean (range), $n(\%)$ & $27.4(14-49.9)$ \\
\hline Unknown & $15(1.7 \%)$ \\
\hline$<18.5$ & $13(1.53 \%)$ \\
\hline $18.5-24.9$ & $291(34.28 \%)$ \\
\hline $25-29$ & $291(34.28 \%)$ \\
\hline$\geq 30$ & $239(28.15 \%)$ \\
\hline Tumor size, $n(\%)$ & $n(\%)$ \\
\hline $\mathrm{TX}$ & $25(2.94)$ \\
\hline $\mathrm{T} 1$ & $210(24.73)$ \\
\hline $\mathrm{T} 2$ & $301(35.45)$ \\
\hline $\mathrm{T} 3$ & $140(16.49)$ \\
\hline $\mathrm{T} 4$ & $173(20.38)$ \\
\hline
\end{tabular}

\begin{tabular}{lc}
\hline Lymph node status, $n(\%)$ & \\
Nx & $293(34.51)$ \\
N0 & $304(35.8)$ \\
N1-N3 & $252(29.68)$ \\
\hline
\end{tabular}

\begin{tabular}{lc}
\hline TNM, $n(\%)$ & \\
I & $176(20.73)$ \\
II & $389(45.82)$ \\
III & $228(26.86)$ \\
IV & $32(3.77)$ \\
\hline
\end{tabular}

\begin{tabular}{lc}
\hline $\begin{array}{l}\text { Histological subtype, } n(\%) \\
\text { Ductal invasive }\end{array}$ & $711(83.7)$ \\
Lobular invasive & $57(6.71)$ \\
Other & $37(4.36)$ \\
\hline Tumor grade, $n(\%)$ & $143(16.84)$ \\
G1 & $375(44.17)$ \\
G2 & $211(24.85)$ \\
G3 & \\
\hline Estrogen receptor status, $n(\%)$ & $605(71.26)$ \\
Positive & $244(28.74)$ \\
Negative & \\
\hline Progesterone receptor status, $n(\%)$ & $537(63.25)$ \\
Positive & $312(36.75)$ \\
Negative & \\
\hline
\end{tabular}

TABle 1: Continued.

\begin{tabular}{lc}
\hline Characteristics & $N=849$ \\
\hline HER 2, $n$ (\%) & \\
Positive & $211(24.85)$ \\
Negative & $601(70.79)$ \\
Unknown & $37(4.36)$ \\
\hline Tumor subtype (IHC4), $n(\%)$ & \\
Luminal A & $298(35.1)$ \\
Luminal B, HER 2- & $172(20.26)$ \\
Luminal B, HER 2+ & $131(15.43)$ \\
Her 2-enriched & $79(9.31)$ \\
Triple negative & $133(15.67)$ \\
\hline
\end{tabular}

TABLE 2: BMI distribution.

\begin{tabular}{lccc}
\hline Characteristics & $\begin{array}{c}\text { Premenopausal } \\
(58.42 \%)\end{array}$ & $\begin{array}{c}\text { Postmenopausal } \\
N=353\end{array}$ & $p$ value \\
& $27.2(15.6-42.8)$ & $27.7(14-49.9)$ & 0.443 \\
\hline $\begin{array}{l}\text { BMI }\left(\mathrm{kg} / \mathrm{m}^{2}\right), \\
\text { range }\end{array}$ & $175(35.7)$ & $120(34.9)$ & \\
\hline $\begin{array}{l}\text { Normal } \\
(18.5-24.9), n(\%)\end{array}$ & $175(35.7)$ & $113(32.8)$ & 0.482 \\
$\begin{array}{l}\text { Overweight } \\
(25-29.9), n(\%)\end{array}$ & $107(31.1)$ & \\
$\begin{array}{l}\text { Obese }(\geq 30), n \\
(\%)\end{array}$ & $131(26.7)$ & & \\
\hline
\end{tabular}

in the premenopausal group (Figure 2). There were no additional correlations found between BMI and the remaining molecular subtypes in either pre- or postmenopausal groups.

In premenopausal patients, increased BMI was associated with increased lymphovascular invasion (LVI) (Figure 3). Such a correlation was not found in the postmenopausal group.

Additional correlations between the BMI and the remaining tumor variables (tumor grade, lymph node involvement, and disease stage) were not significant in either pre- or postmenopausal women (Tables 3 and 4).

\section{Discussion}

In this study, we describe the prevalence of obesity in Colombian breast cancer patients and analyze the relationship of BMI with prognostic factors. The prevalence of obesity in our study population was $28.15 \%$. While this prevalence is comparable to that reported for breast cancer patients in the United States [22], it is greater than the obesity prevalence described in European studies (13\% to $20 \%)[16,23,24]$. Collectively, these data suggest that there is a demographic factor in the prevalence of obesity in breast cancer patients [25].

Previous studies have shown overweight and obesity to be related to postmenopausal breast cancer. Several mechanisms have been proposed to explain this observation, including increased circulating estrogen levels and estrogen aromatization in adipose tissue. The latter decreases levels of sex 


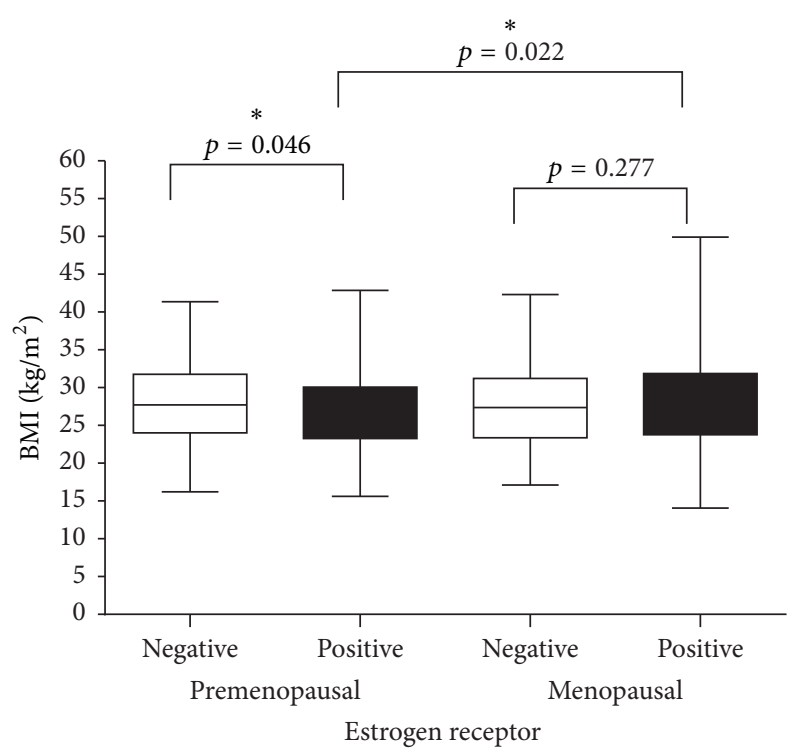

(a)

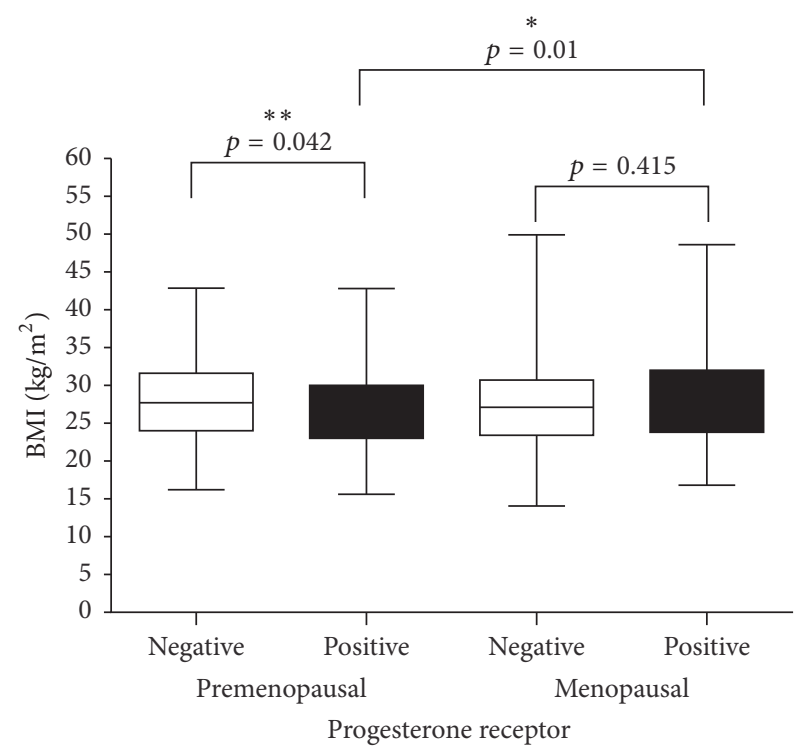

(b)

FIGURE 1: BMI and hormone receptor status in premenopausal and postmenopausal breast cancer patients. $*$ and $* *$ refer to the level of significance.

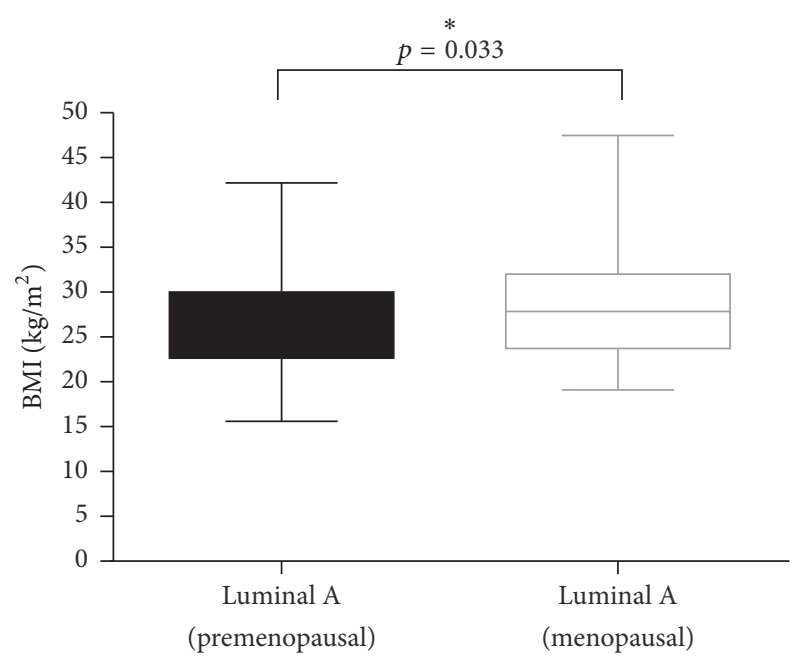

FIGURE 2: Higher BMI is associated with luminal A tumors in postmenopausal women. * refers to the level of significance.

hormone-binding globulin (SHBG), affecting aromatase gene expression regulation $[23,26]$. However, unlike previous studies, an association between BMI and menopausal status was not statistically significant in our population. These results may be partly explained by the twofold increased prevalence of obesity in the premenopausal group in our study compared to that of previous reports $(26.7 \%$ versus $10-14 \%)[22,23]$.

Obese breast cancer patients are often associated with advanced stage disease, larger tumors, and axillary lymph node-positive status, partly due to delayed diagnoses and

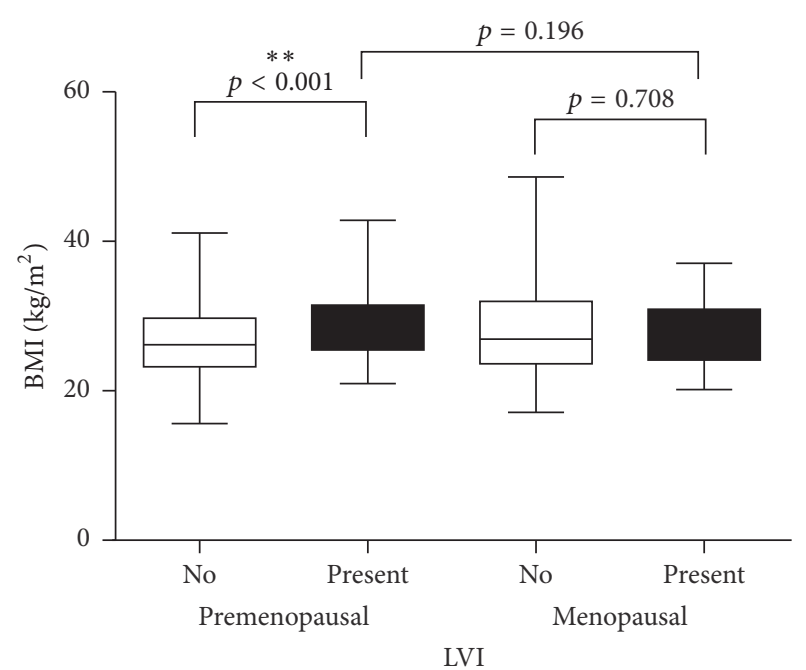

FIgURE 3: LVI is associated with higher BMI in premenopausal breast cancer patients. $* *$ refers to the level of significance.

technical difficulties in palpation of the tumors [27-29]. However, in this study we did not find a statistically significant association between BMI and tumor size, lymph nodestatus, disease stage, or histological grade in the current study groups. It is plausible that a larger sample size may be required to establish this association.

In the context of lymphovascular invasion (LVI), Demirkan and colleagues showed that, in breast cancer patients with $\mathrm{BMI} \geq 30 \mathrm{~kg} / \mathrm{m}^{2}$, LVI was an independent prognostic factor of poor outcome [30]. In agreement with 
TABLE 3: BMI and tumor histopathologic features in premenopausal Colombian breast cancer patients.

\begin{tabular}{|c|c|c|c|c|}
\hline \multirow{2}{*}{ Tumor characteristics } & \multicolumn{4}{|c|}{ BMI } \\
\hline & Normal & Overweight & Obese & $p$ value \\
\hline \multicolumn{5}{|l|}{ Tumor size $n,(\%)$} \\
\hline $\mathrm{TX}$ & $5(2.9)$ & $4(2.3)$ & $2(1.5)$ & \multirow{5}{*}{0.821} \\
\hline $\mathrm{T} 1$ & $45(26.0)$ & $39(22.2)$ & $26(19.7)$ & \\
\hline $\mathrm{T} 2$ & $60(34.7)$ & $59(33.5)$ & $52(39.4)$ & \\
\hline $\mathrm{T} 3$ & $31(17.9)$ & $39(22.2)$ & $23(17.4)$ & \\
\hline $\mathrm{T} 4$ & $32(18.5)$ & $35(19.9)$ & $29(22.0)$ & \\
\hline \multicolumn{5}{|l|}{ Lymph nodes $n$, (\%) } \\
\hline $\mathrm{Nx}$ & $66(13.7)$ & $53(11)$ & $42(8.7)$ & \multirow{3}{*}{0.412} \\
\hline No & $57(11.8)$ & $70(14.5)$ & $55(11.4)$ & \\
\hline N1-N3 & $50(10.4)$ & $53(11)$ & $35(7.2)$ & \\
\hline \multicolumn{5}{|l|}{ TNM $n(\%)$} \\
\hline I & $35(7.2)$ & $34(7.0)$ & $22(4.5)$ & \multirow{4}{*}{0.847} \\
\hline II & $83(17.26)$ & $86(17.8)$ & $68(14.1)$ & \\
\hline III & $42(8.7)$ & $49(10.1)$ & $37(7.6)$ & \\
\hline IV & $8(1.66)$ & $4(0.8)$ & $3(0.6)$ & \\
\hline \multicolumn{5}{|l|}{ Tumor grade } \\
\hline G1 & $36(20.6)$ & $30(17.1)$ & $17(13.0)$ & \multirow{3}{*}{0.142} \\
\hline G2 & $69(39.4)$ & $83(47.4)$ & $61(46.6)$ & \\
\hline G3 & $41(23.5)$ & $45(25.7)$ & $40(30.5)$ & \\
\hline \multicolumn{5}{|l|}{ Estrogen receptor status } \\
\hline Positive & $132(75.4)$ & $121(69.1)$ & $83(63.4)$ & \multirow{2}{*}{0.072} \\
\hline Negative & $43(24.6)$ & $54(30.9)$ & $48(36.6)$ & \\
\hline \multicolumn{5}{|c|}{ Progesterone receptor status } \\
\hline Positive & $122(69.7)$ & $111(63.4)$ & $73(55.7)$ & \multirow{2}{*}{0.042} \\
\hline Negative & $53(30.3)$ & $64(36.6)$ & $58(44.3)$ & \\
\hline \multicolumn{5}{|l|}{ HER2 status, $n(\%)$} \\
\hline Negative & $123(71.1)$ & $115(65.3)$ & $95(72.0)$ & \multirow{3}{*}{0.384} \\
\hline Positive & $42(24.3)$ & $54(30.7)$ & $35(26.5)$ & \\
\hline Unknown & $8(4.6)$ & $7(4.0)$ & $2(1.5)$ & \\
\hline \multicolumn{5}{|c|}{ Molecular subtype (IHC4) } \\
\hline Luminal A & $61(34.9)$ & $57(32.6)$ & $43(32.8)$ & \multirow{5}{*}{0.397} \\
\hline Luminal B, HER 2- & $38(21.8)$ & $32(18.3)$ & $21(16.0)$ & \\
\hline Luminal B, HER 2+ & $30(17.1)$ & $33(18.9)$ & $19(14.5)$ & \\
\hline Her2-enriched & $13(7.4)$ & $20(11.4)$ & $16(12.2)$ & \\
\hline Triple negative & $25(14.3)$ & $26(14.9)$ & $30(22.9)$ & \\
\hline
\end{tabular}

previous studies [31], our data show a strong association of LVI with BMI > 25 in the premenopausal group.

In this study, compared to premenopausal women, postmenopausal women with higher BMIs were found to be associated with luminal A tumors. This is consistent with previous reports describing a positive correlation between hormone receptor status and obese postmenopausal breast cancer patients in Europe [32]. On the other hand, a study by Millikan and colleagues reported an inverse relationship between BMI and hormone receptor status in premenopausal women [33], in agreement with our data. Additional studies suggest that tumors in obese breast cancer patients, particularly ER/PR-negative tumors, are dependent of growth factors such as insulin, insulin growth factor 1 (IGF1), and leptin [34].

This study is the first report, to our knowledge, of obesity prevalence in Colombian breast cancer patients. Our results indicate that there is a high prevalence of obesity in our study population. Because obesity is a recognized risk factor for poor outcome in breast cancer patients, especially in premenopausal females, Colombian women may be at higher risk of developing more aggressive disease. Future studies to further validate our observations are needed in order to implement multidisciplinary clinical care practices that may 
TABLE 4: BMI and tumor histopathologic features in postmenopausal Colombian breast cancer patients.

\begin{tabular}{|c|c|c|c|c|}
\hline \multirow{2}{*}{ Tumor characteristics } & \multicolumn{4}{|c|}{ BMI } \\
\hline & Normal & Overweight & Obese & $p$ value \\
\hline \multicolumn{5}{|l|}{ Lymph nodes $n,(\%)$} \\
\hline $\mathrm{Nx}$ & $36(10.5)$ & $45(13.2)$ & $44(12.9)$ & \multirow{3}{*}{0.068} \\
\hline No & $45(13.2)$ & $29(8.5)$ & $39(11.4)$ & \\
\hline N1-N3 & $37(10.8)$ & $41(12)$ & $24(22)$ & \\
\hline \multicolumn{5}{|l|}{ TNM $n(\%)$} \\
\hline I & $26(7.6)$ & $27(7.9)$ & $28(8.2)$ & \multirow{4}{*}{0.879} \\
\hline II & $51(15.0)$ & $48(14.1)$ & $45(13.2)$ & \\
\hline III & $33(9.7)$ & $34(10)$ & $26(7.6)$ & \\
\hline IV & $6(1.7)$ & $2(0.5)$ & $5(1.47)$ & \\
\hline \multicolumn{5}{|l|}{ Tumor grade } \\
\hline G1 & $23(19.2)$ & $16(14.2)$ & $17(15.9)$ & \multirow{3}{*}{0.900} \\
\hline G2 & $52(43.3)$ & $49(43.4)$ & $51(47.7)$ & \\
\hline G3 & $29(24.2)$ & $28(24.8)$ & $24(22.4)$ & \\
\hline \multicolumn{5}{|l|}{ Estrogen receptor status } \\
\hline Positive & $85(70.8)$ & $86(76.1)$ & $80(74.8)$ & \multirow{2}{*}{0.635} \\
\hline Negative & $35(29.2)$ & $27(23.9)$ & $27(25.2)$ & \\
\hline \multicolumn{5}{|c|}{ Progesterone receptor status } \\
\hline Positive & $70(58.3)$ & $73(64.6)$ & $71(66.4)$ & \multirow{2}{*}{0.415} \\
\hline Negative & $50(41.7)$ & $40(35.4)$ & $36(33.6)$ & \\
\hline \multicolumn{5}{|l|}{ HER2 status, $n(\%)$} \\
\hline Negative & $83(70.3)$ & $86(74.8)$ & $83(77.6)$ & \multirow{3}{*}{0.632} \\
\hline Positive & $29(24.6)$ & $24(20.9)$ & $22(20.6)$ & \\
\hline Unknown & $6(5.1)$ & $5(4.3)$ & $2(1.9)$ & \\
\hline \multicolumn{5}{|c|}{ Molecular subtype (IHC4) } \\
\hline Luminal A & $46(38.3)$ & $34(30.1)$ & $46(43.0)$ & \multirow{5}{*}{0.287} \\
\hline Luminal B, HER 2- & $20(16.7)$ & $36(31.9)$ & $21(19.6)$ & \\
\hline Luminal B, HER 2+ & $19(15.8)$ & $15(13.3)$ & $13(12.1)$ & \\
\hline Her2-enriched & $11(9.2)$ & $7(6.2)$ & $9(8.4)$ & \\
\hline Triple negative & $18(15.0)$ & $17(15.0)$ & $16(15.0)$ & \\
\hline
\end{tabular}

provide better care and targeted treatment for breast cancer patients.

\section{Disclosure}

This research did not receive any specific grant from funding agencies in the public, commercial, or not-for-profit sectors.

\section{Conflicts of Interest}

The authors declare that there are no conflicts of interest regarding the publication of this paper.

\section{Acknowledgments}

The authors would like to thank Katherine Drews-Elger for critically reading this manuscript and her helpful suggestions. This work was supported by Fundación Colombiana de Cancerología-Clínica Vida, CES University.

\section{References}

[1] S. J. Ioannides, P. L. Barlow, J. M. Elwood, and D. Porter, "Effect of obesity on aromatase inhibitor efficacy in postmenopausal, hormone receptor-positive breast cancer: a systematic review," Breast Cancer Research and Treatment, vol. 147, no. 2, pp. 237248, 2014.

[2] T. Kelly, W. Yang, C.-S. Chen, K. Reynolds, and J. He, "Global burden of obesity in 2005 and projections to 2030," International Journal of Obesity, vol. 32, no. 9, pp. 1431-1437, 2008.

[3] D. P. Guh, W. Zhang, N. Bansback, Z. Amarsi, C. L. Birmingham, and A. H. Anis, "The incidence of co-morbidities related to obesity and overweight: a systematic review and meta-analysis," BMC Public Health, vol. 9, article 88, 2009.

[4] R. L. Siegel, K. D. Miller, and A. Jemal, "Cancer statistics, 2016," CA: A Cancer Journal for Clinicians, vol. 66, no. 1, pp. 7-30, 2016.

[5] J. Ferlay, I. Soerjomataram, R. Dikshit et al., "Cancer incidence and mortality worldwide: sources, methods and major patterns in GLOBOCAN 2012," International Journal of Cancer, 2014. 
[6] W. Gradishar and K. E. Salerno, "NCCN guidelines update: breast cancer," Journal of the National Comprehensive Cancer Network, vol. 14, no. 5, pp. 641-644, 2016.

[7] W. J. Gradishar, B. O. Anderson, R. Balassanian et al., "Invasive breast cancer version 1.2016, NCCN clinical practice guidelines in oncology," Journal of the National Comprehensive Cancer Network, vol. 14, pp. 324-354, 2016.

[8] M. Sogaard, R. W. Thomsen, K. S. Bossen, H. T. Sorensen, and M. Norgaard, "The impact of comorbidity on cancer survival: a review," Clinical Epidemiology, vol. 5, pp. 3-29, 2013.

[9] S. Niraula, A. Ocana, M. Ennis, and P. J. Goodwin, "Body size and breast cancer prognosis in relation to hormone receptor and menopausal status: a meta-analysis," Breast Cancer Research and Treatment, vol. 134, no. 2, pp. 769-781, 2012.

[10] S. D. Hursting, L. M. Lashinger, K. W. Wheatley et al., "Reducing the weight of cancer: mechanistic targets for breaking the obesity-carcinogenesis link," Best Practice \& Research Clinical Endocrinology \& Metabolism, vol. 22, pp. 659-669, 2008.

[11] A. G. Renehan, M. Tyson, M. Egger, R. F. Heller, and M. Zwahlen, "Body-mass index and incidence of cancer: a systematic review and meta-analysis of prospective observational studies," The Lancet, vol. 371, no. 9612, pp. 569-578, 2008.

[12] J. Park, T. S. Morley, M. Kim, D. J. Clegg, and P. E. Scherer, “Obesity and cancer-mechanisms underlying tumour progression and recurrence," Nature Reviews Endocrinology, vol. 10, no. 8, pp. 455-465, 2014

[13] S. Kann, S. M. Schmid, M. Eichholzer, D. J. Huang, E. Amann, and U. Guth, "The impact of overweight and obesity on breast cancer: data from Switzerland, so far a country little affected by the current global obesity epidemic," Gland Surgery, vol. 3, pp. 181-197, 2014.

[14] D. S. M. Chan, A. R. Vieira, D. Aune et al., "Body mass index and survival in women with breast cancer-systematic literature review and meta-analysis of 82 follow-up studies," Annals of Oncology, vol. 25, no. 10, pp. 1901-1914, 2014.

[15] R. Jain, H. D. Strickler, E. Fine, and J. A. Sparano, "Clinical studies examining the impact of obesity on breast cancer risk and prognosis," Journal of Mammary Gland Biology and Neoplasia, vol. 18, no. 3-4, pp. 257-266, 2013.

[16] M. Eichholzer, S. M. Schmid, F. Bovey et al., "Impact of overweight and obesity on postmenopausal breast cancer: analysis of 20-year data from Switzerland," Archives of Gynecology and Obstetrics, vol. 285, no. 3, pp. 797-803, 2012.

[17] R. Fortich and J. D. Gutierrez, "Los determinantes de la obesidad en Colombia," Revista Economía \& Región, 2011.

[18] F. Manzur, S. Alvear, and A. Alayón, "El perfil epidemiológico del sobrepeso y la obesidad y sus principales comorbilidades en la ciudad de Cartagena de Indias," Revista Colombiana de Cardiología, vol. 16, pp. 194-200, 2009.

[19] K. Acosta, "La obesidad y su concentración según nivel socioeconómico en Colombia," Revista de Economía del Rosario, vol. $16,2016$.

[20] C. L. Ogden, M. D. Carroll, B. K. Kit, and K. M. Flegal, "Prevalence of childhood and adult obesity in the United States, 2011-2012," The Journal of the American Medical Association, vol. 311, no. 8, pp. 806-814, 2014.

[21] A. Goldhirsch, E. P. Winer, A. S. Coates et al., "Personalizing the treatment of women with early breast cancer: highlights of the St Gallen International expert consensus on the primary therapy of early breast cancer 2013. annals of oncology," Annals of Oncology, vol. 24, pp. 2206-2223, 2013.
[22] J. J. Dignam, K. Wieand, K. A. Johnson et al., "Effects of obesity and race on prognosis in lymph node-negative, estrogen receptor-negative breast cancer," Breast Cancer Research and Treatment, vol. 97, no. 3, pp. 245-254, 2006.

[23] N. Biglia, E. Peano, P. Sgandurra et al., "Body mass index (BMI) and breast cancer: impact on tumor histopatologic features, cancer subtypes and recurrence rate in pre and postmenopausal women," Gynecological Endocrinology, vol. 29, no. 3, pp. 263267, 2013.

[24] M. Eichholzer, D. J. Huang, A. Modlasiak et al., "Impact of body mass index on prognostically relevant breast cancer tumor characteristics," Breast Care, vol. 8, no. 3, pp. 192-198, 2013.

[25] A. E. Connor, R. N. Baumgartner, D. Yang et al., "Differences between hispanic and non-hispanic white women with breast cancer for clinical characteristics and their correlates," Annals of Epidemiology, vol. 23, pp. 227-232, 2013.

[26] C. la Vecchia, S. H. Giordano, G. N. Hortobagyi, and B. Chabner, "Overweight, obesity, diabetes, and risk of breast cancer: interlocking pieces of the puzzle," Oncologist, vol. 16, no. 6, pp. 726-729, 2011.

[27] J. R. Daling, K. E. Malone, D. R. Doody, L. G. Johnson, J. R. Gralow, and P. L. Porter, "Relation of body mass index to tumor markers and survival among young women with invasive ductal breast carcinoma," Cancer, vol. 92, no. 4, pp. 720-729, 2001.

[28] S. Loi, R. L. Milne, M. L. Friedlander et al., "Obesity and outcomes in premenopausal and postmenopausal breast cancersource: cancer epidemiology, biomarkers \& prevention research," The American Society of Preventive Oncology, vol. 14, pp. 1686-1691, 2005.

[29] P. E. Abrahamson, M. D. Gammon, M. J. Lund et al., "General and abdominal obesity and survival among young women with breast cancersource: cancer epidemiology, biomarkers \& prevention," The American Society of Preventive Oncology, vol. 15, pp. 1871-1877, 2006.

[30] B. Demirkan, A. Alacacioglu, and U. Yilmaz, "Relation of body mass index (BMI) to disease free (DFS) and distant disease free survivals (DDFS) among Turkish women with operable breast carcinoma," Japanese Journal of Clinical Oncology, vol. 37, no. 4, pp. 256-265, 2007.

[31] F. P. Turkoz, M. Solak, I. Petekkaya et al., "The prognostic impact of obesity on molecular subtypes of breast cancer in premenopausal women," Journal of BUON, vol. 18, pp. 335-341, 2013.

[32] B. O. Mæhle, S. Tretli, R. Skjærven, and T. Thorsen, "Premorbid body weight and its relations to primary tumour diameter in breast cancer patients; its dependence on estrogen and progesteron receptor status," Breast Cancer Research and Treatment, vol. 68, no. 2, pp. 159-169, 2001.

[33] R. C. Millikan, B. Newman, C.-K. Tse et al., "Epidemiology of basal-like breast cancer," Breast Cancer Research and Treatment, vol. 109, no. 1, pp. 123-139, 2008.

[34] L. Vona-Davis and D. P. Rose, "Adipokines as endocrine, paracrine, and autocrine factors in breast cancer risk and progression," Endocrine-Related Cancer, vol. 14, no. 2, pp. 189-206, 2007. 


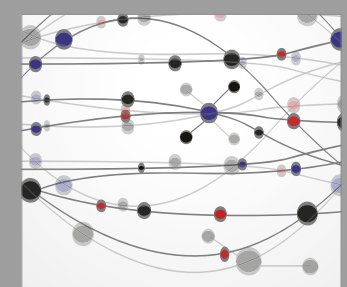

The Scientific World Journal
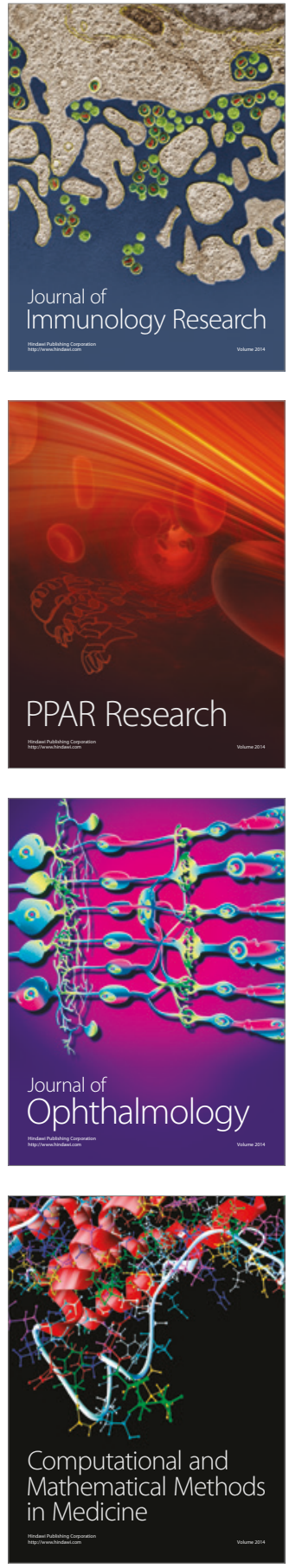

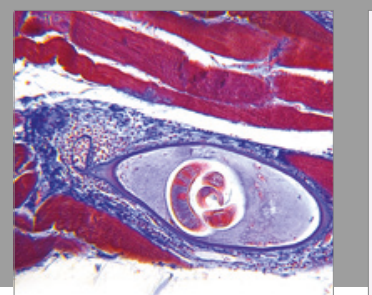

Gastroenterology Research and Practice
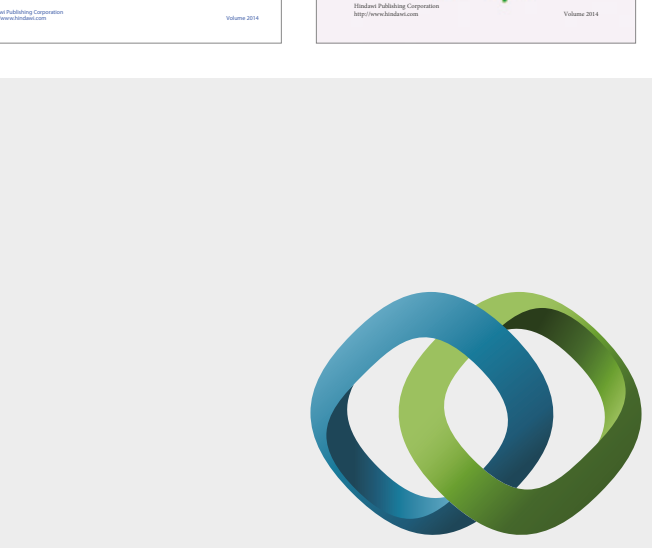

\section{Hindawi}

Submit your manuscripts at

https://www.hindawi.com
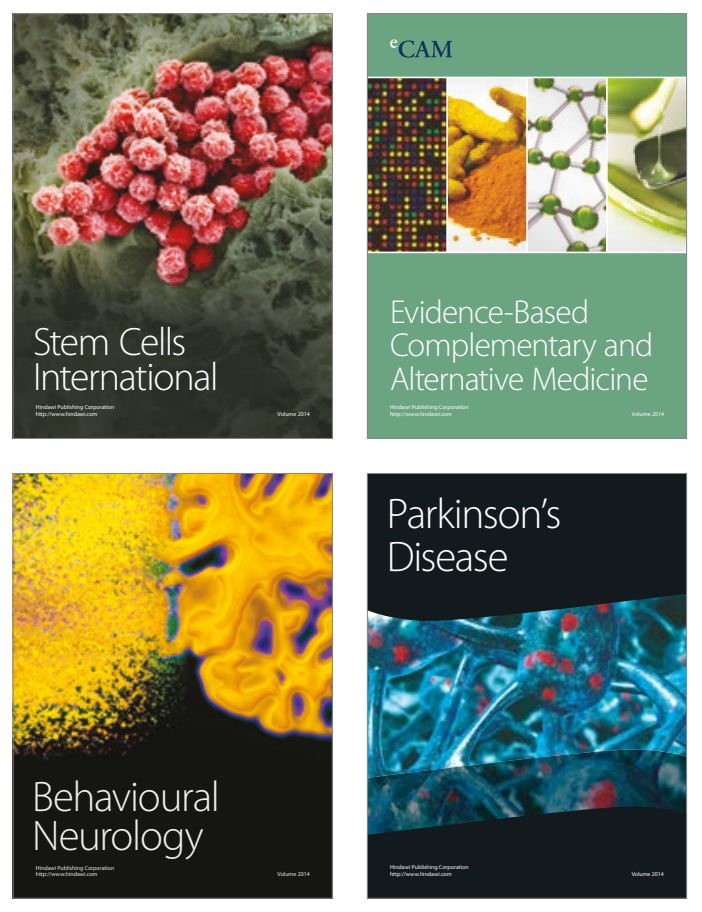
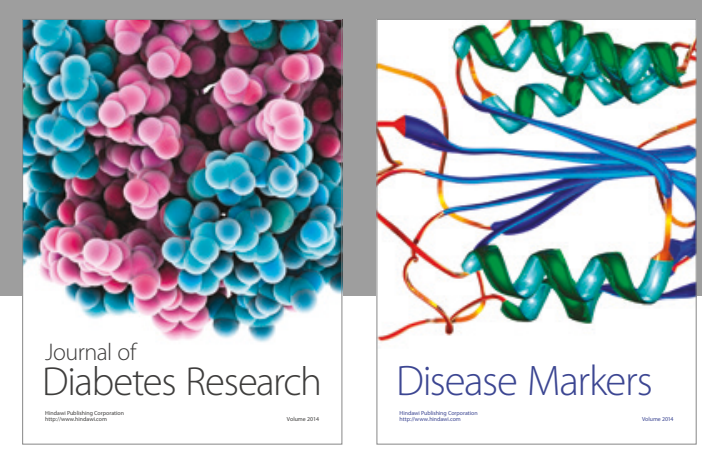

Disease Markers
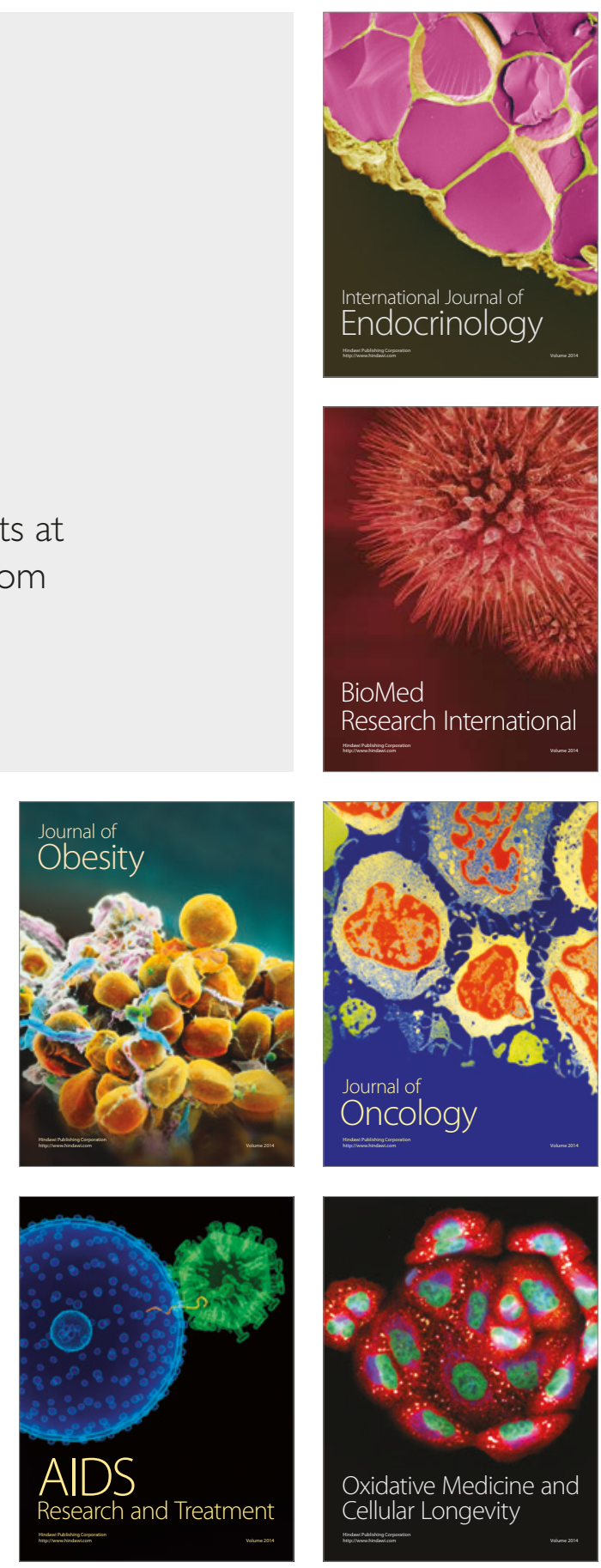